\title{
Seasonal composition, abundance and biomass of the subestuarine fish assemblage in Solís Chico (Río de la Plata estuary, Uruguay)
}

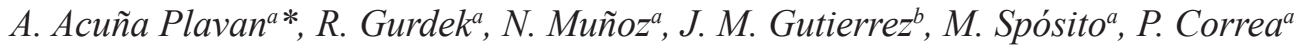 \\ and A. Caride ${ }^{a}$ \\ ${ }^{a}$ Oceanografía y Ecología Marina, Facultad de Ciencias, Universidad de la República - Udelar, Uruguay, \\ Iguá 4225, 11400, Montevideo, Uruguay

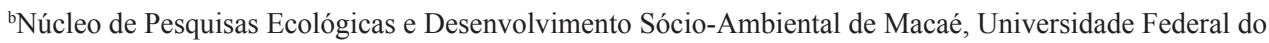 \\ Rio de Janeiro - UFRJ, Avenida São José do Barreto, São José do Barreto, CEP 279650450, Macaé, RJ, Brazil \\ *e-mail: acuplavan@gmail.com
}

Received: February 22, 2016 - Accepted: April 14, 2016 - Distributed: August 31, 2017

(With 4 figures)

\begin{abstract}
The large estuaries can present long narrow branches called subestuaries or tidal creeks. These types of subsystems are distributed along the Uruguayan coast of the Río de la Plata estuary and are very important as nursery and refuge areas for fish. For the first time, the seasonal composition and abundance of the fish community of the Solís Chico subestuary was studied by using beach and gill nets. Fourteen species, mainly euryhaline (86\%) presented a significant representation of juvenile stages. The fish community was dominated by Odontesthes argentinensis, Platanichthys platana, Mugil liza, Brevoortia aurea, Micropogonias furnieri and Paralichthys orbignyanus, similar to adjacent subestuaries. While Micropogonias furnieri and B. aurea were the most abundant species, some other species were rarely caught. A seasonal variation of the fish assemblage abundance was detected, with higher values in autumn showing a positive correlation with temperature. Species that complete their life cycle in the Río de la Plata estuary, some of which are relevant to fisheries (64\% of the analyzed species) were captured in the Solís Chico subestuary. The importance of this environment as a transitional system for some estuarine fish species is advised.
\end{abstract}

Keywords: estuary, fish community, ecological status, ichthyofauna, temporal variability.

\section{Composição, abundância e biomasa sazonal da assembleia de peixes no subestuário do Solís Chico (Estuário do Río de la Plata, Uruguay)}

\begin{abstract}
Resumo
Os grandes estuários podem apresentar longos ramos estreitos chamados subestuários e riachos de maré. Estes subsistemas estão distribuídos ao longo da costa uruguaia no estuário do Río de la Plata e são muito importantes como áreas de reprodução e refúgio para os peixes. Pela primeira vez, a composição sazonal e abundância da comunidade de peixes do subestuário Solís Chico foi estudada usando redes de arrasto de praia e rede de emalhar. Quatorze espécies com predominância das eurialinas foram capturadas, havendo uma representação significativa das fases juvenis e espécies alvo para a pesca. A comunidade de peixes foi dominada por Odontesthes argentinensis, Platanichthys platana, Mugil liza, Brevoortia aurea, Micropogonias furnieri e Paralichthys orbignyanus, semelhante aos subestuários adjacentes. Enquanto, $M$. furnieri e $B$. aurea foram as espécies com maior número de individuos. Solís Chico apresentou espécies exclusivas com baixa abundância e ocorrência. Foi verificada uma variação sazonal da abundância de peixes, com valores maiores no outono, mostrando uma correlação positiva com a temperatura. Algumas espécies relevantes para a pesca que completam seu ciclo de vida no estuário do Río de la Plata foram capturadas (64\% das espécies estudadas) no subestuário Solís Chico, indicando a importância deste ambiente como um sistema transitório para algumas espécies estuarinas de peixes.
\end{abstract}

Palavras-chave: estuários, comunidade de peixes, estado ecológico, ictiofauna, variabilidade temporal. 


\section{Introduction}

Large estuaries sometimes present particularly long narrow branches that have their own freshwater supply. Such water bodies can be called subestuaries or tidal creek subsystems of the main estuary. A true estuary is connected to the ocean; its salinity therefore always reaches oceanic values at the mouth. Instead, a subestuary is connected to the main estuary, where the salinity can vary significantly (Tomczak, 1998). Therefore, subestuarine characteristics depend on the incidence of larger water bodies as estuaries and freshwater input from rivers (Uncles and Stephens, 2010). These estuarine environments are utilized by some fish species during particular periods of their life cycle, defining estuarine habitats as temporary spawning and feeding grounds (Able, 2005; Lellis et al., 2008). In the shallow habitats of Chesapeake Bay subestuaries, juvenile stages predominate since they are protected from bigger predators and find abundant food to grow and successfully complete their life cycle in the area (Uphoff Junior et al., 2011). In this regard, subestuarine systems located along the Uruguayan coast play an important functional role for fish that develop their life cycle between these subsystems and the Río de la Plata estuary, including target fisheries relevant species (Acuña et al., 2015). In this sense, the Pando subestuary has been identified as a nursery area for juvenile fish of economic importance for Uruguay and Argentina, while the Solís Grande subestuary has been defined as an area mostly used by early stages of development of fish (Acuña-Plavan et al., 2010; Gurdek and Acuña-Plavan, 2014). Unlike, a third subestuary, the Solís Chico is an scarcely studied ecosystem particularly with regard to its fish fauna composition. It is located adjacent to the other two subsystems, and thus it is expected that it may show a similar fish fauna. Given this, the aim of this study was to determine the species composition, abundance and biomass of the fish assemblage of the Solís Chico subestuary and analyze the seasonal variability.

\section{Material and Methods}

\subsection{Study area}

The Solís Chico subestuary $\left(34^{\circ} 45^{\prime} \mathrm{S}, 55^{\circ} 41^{\prime} \mathrm{W}\right)$ (Figure 1) is located in the Uruguayan coast of the Río de la Plata estuary. This system presents a drainage basin of $653 \mathrm{~km}^{2}$, a length of $47 \mathrm{~km}$, an average flow of $8.7 \mathrm{~m}^{3} \mathrm{~s}^{-1}$ and a maximum width of $280 \mathrm{~m}$ (Cayssials et al., 2000). The Solís Chico subestuary presents an extensive salt marsh area in its lower portion, characterized by halophytes and hydrophytes and a large population of crabs, representing the highest natural productivity of the area (Giménez, 2003; Geo-Uruguay, 2008).

\subsection{Sampling}

Three surveys were performed in spring 2011, autumn and winter 2012. Fish were captured by beach seine net (12 $\mathrm{m}$ long with a central bag of $6.70 \mathrm{~m}$ long and, mesh size $12 \mathrm{~mm}$ ) and two sets of gill nets ( $40 \mathrm{~m}$ long, $1.7 \mathrm{~m}$ high, each one with 4 different mesh sizes). The last nets were set in the subestuary for an average of 12 hours (between 8 p.m. until 8 and $9 \mathrm{am}$ ). Twelve hauls were made during each survey, six on each margin of the estuary, covering an area of ca. $300 \mathrm{~m}^{2}$ per haul. Collected fish were identified to species level according to Ringuelet et al. (1967), Figueiredo and Menezes (1978), Figueiredo and Menezes (1980), Menezes and Figueiredo (1980), Dawson (1982), Menni et al. (1984), Menezes and Figueiredo (1985), Figueiredo and Menezes (2000), Bemvenuti (2002), Marceniuk (2005), Dyer (2006), Rangel and Guimarães (2010). Each individual was counted, measured to the nearest $0.1 \mathrm{~cm}$ and weighted to the nearest $0.1 \mathrm{~g}$.

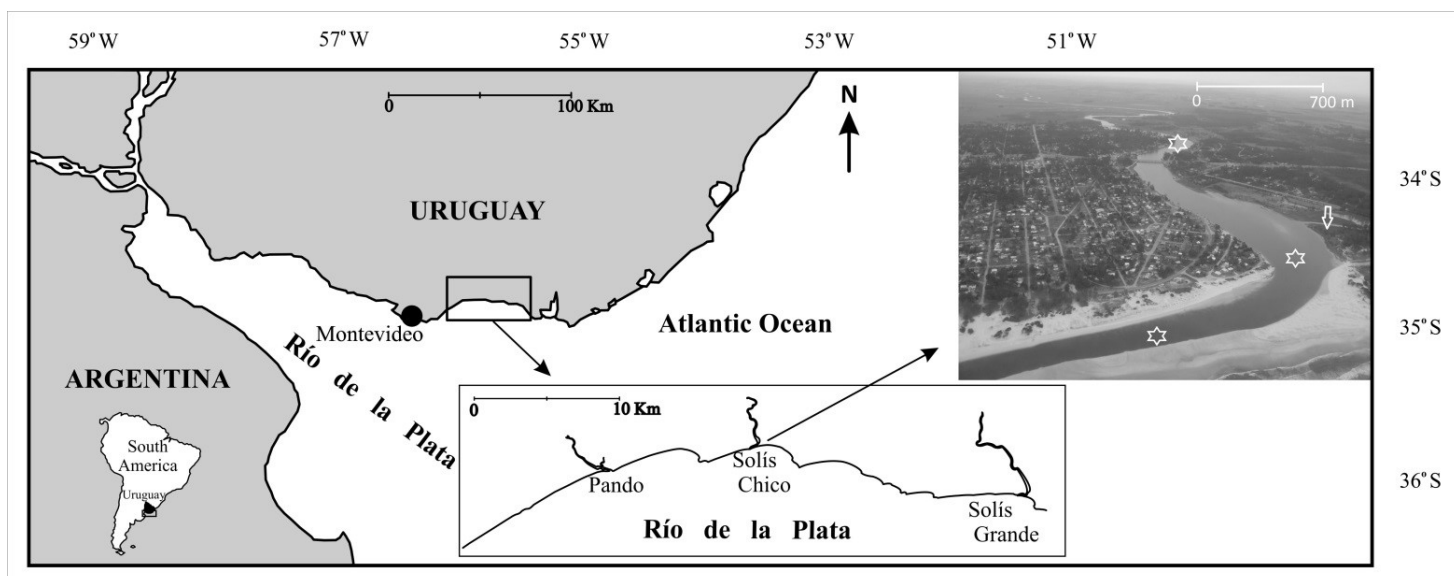

Figure 1. Location of the study area in the lower Solís Chico subestuary and subestuaries adjacent (Pando and Solís Grande) in Uruguayan coast of the Río de la Plata. Sampling locations by beach seine net (middle star) and gill nets (upper and lower stars) and the salt marsh zone (white arrow) are indicated. 
Additionally, three replicates of temperature $\left({ }^{\circ} \mathrm{C}\right)$, salinity and dissolved oxygen $(\mathrm{mg} / \mathrm{l})$ of water were measured directly in the field with multiparameter Ysi Pro-plus (USA) with a temperature resolution of $0.1^{\circ} \mathrm{C}, 0.01$ for salinity and $0.01 \mathrm{mg} / 1$ for dissolved oxygen.

\subsection{Data analysis}

Fish biomass and abundance captured by beach seine net were only expressed in grams and number of individuals per $1000 \mathrm{~m}^{2}$, respectively. These values were estimated for total sample period and seasons (spring 2011, autumn and winter 2012). The species collected with the gill net are just used to present his record in this gear.

The frequency of occurrence was calculated according to the presence of each species in each haul during the study period. These values were related to their relative abundance and presented in an Olmstead-Tukey diagram (modified by González-Acosta et al., 2005). In the scatter diagram, two reference lines show the median frequency (X-axis) and median abundance (Y-axis) of fish species in Solis Chico subestuary. The hierarchical classification of species was made taking into account the following criteria:

Dominant: species with frequency and relative abundance higher than the average for each variable.

Common: species with relative abundance lower than the mean, but relative frequency higher than the mean.

Occasional: species with relative abundance higher than the mean and relative frequency lower than the mean.

Rare: species with relative abundance and frequency lower than mean abundance and frequencies.

Temporal variability in fish assemblage composition and environmental factors were examined using parametric and no-parametric statistical techniques. Assumptions of normality and homogeneity of variance were evaluated by Shapiro-Wilk test (Shapiro and Wilk, 1965) and the Levene's test, respectively. Subsequently a parametric test was applied for analysis of variance (ANOVA) or a non-parametric (Kruskal-Wallis), depending on the fulfillment of the assumptions. Whenever significant differences were found, the Student-Newman-Keuls Method (SNK) and Dunn's Method were used respectively.

Analysis of BIO-ENV was used to estimate the influence of temperature, salinity and dissolved oxygen on community composition (abundance of fish) (PRIMER v.6.0 software package) (Clarke and Warwick, 1994). This process selects the abiotic variables that maximize the correlation rank (p) between the biotic and abiotic (dis) similarity matrices (Bray Curtis for biota, and Euclidean distance for environmental variables). Their rank was compared through a Spearman coefficient (p) (Clarke, 1993; Clarke \& Warwick, 2001).The significance level used was $\alpha=0.05$ (Sokal and Rohlf, 1969).

\section{Results}

\subsection{Environmental factors}

The average temperature in spring $2011\left(15 \pm 0.8^{\circ} \mathrm{C}\right)$ was similar to that of the winter $2012\left(15 \pm 0.2^{\circ} \mathrm{C}\right)$, and lower to than in the autumn $2012\left(18 \pm 0.6^{\circ} \mathrm{C}\right)(\mathrm{SNK}$, $\mathrm{p}<0.05$ ) (Figure 2). In contrast, the average salinity showed a decline from spring $2011(21 \pm 6.0)$, achieving significantly lower values in winter $2012(10 \pm 2.1)$ (Dunn's Method, $\mathrm{p}<0.05$ ) (Figure 2). The average dissolved oxygen values ranged between $6.0 \pm 5.4$ and $13 \pm 2.3 \mathrm{mg} / \mathrm{l}$, with significant differences between periods (SNK, p < 0.05) (Figure 2).

\subsection{Fish composition}

A total of 523 specimens corresponding to 14 species (86\% euryhaline) and 11 families were caught in the Solís Chico subestuary (Table 1). In terms of species richness, Clupeidae and Sciaenidae were the most numerous families, represented by two and three species, respectively. Micropogonias furnieri (Desmarest, 1823) $\left(54.6 \pm 29.9\right.$ individuals $\left.\times 1000 \mathrm{~m}^{2}\right)$ and Brevoortia aurea (Agassiz, 1829) $\left(46.8 \pm 31.8\right.$ individuals $\left.\times 1000 \mathrm{~m}^{2}\right)$ presented the highest number of individuals, whereas B. aurea $\left(286.4 \pm 448.3\right.$ grams $\left.\times 1000 \mathrm{~m}^{2}\right)$, Cyprinus carpio (Linnaeus, 1758) (7815 grams $\times 1000 \mathrm{~m}^{2}$ ), Mugil liza Günther $1880\left(155.4 \pm 173.2\right.$ grams $\left.\times 1000 \mathrm{~m}^{2}\right)$ and Odontesthes argentinensis (Valenciennes, 1836) $\left(249.4 \pm 218.7\right.$ grams $\left.\times 1000 \mathrm{~m}^{2}\right)$ were the most abundant in biomass. A group of species with low abundance and biomass were constituted by the gobies, blennies and syngnathids, represented by adult phases. Seven species were collected by gill nets. Menticirrhus americanus (Linnaeus, 1758) (one individual; $18.0 \mathrm{~cm}$ ) and Pogonias cromis (Linné, 1766) (three individuals; $42.3 \mathrm{~cm} \pm 17.2$ ) were species only captured by gill nets. The fish assemblage included a wide range of lengths, mostly represented by juveniles (Table 1). Adults individuals were usually captured by gill nets (58 individuals) represented by L. grossidens $(20.1 \mathrm{~cm})$,

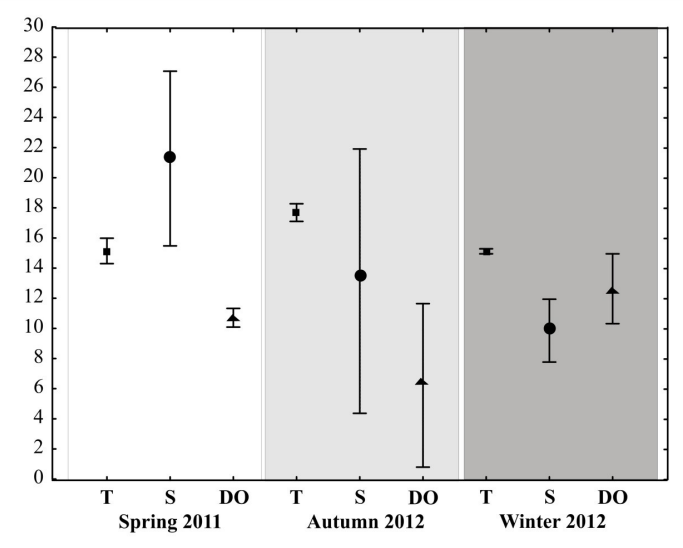

Figure 2. Average values ( \pm standard deviation) of temperature $\left(\mathrm{T}-{ }^{\circ} \mathrm{C}\right)$, salinity $(\mathrm{S})$ and dissolved oxygen (DO-mg/l) of water in Solís Chico subestuary during spring 2011 and autumn and winter 2012 . 
Table 1. List of species (families, species, common name) captured by beach seine net and gill net in Solis Chico subestuary. Average abundance \pm standard deviation (number of individuals $\times 1000 \mathrm{~m}^{2}$ ) and biomass \pm standard deviation $\left(\right.$ grams $\left.\times 1000 \mathrm{~m}^{2}\right)$ of species sampled in the Solís Chico subestuary by beach seine net. Mean length $(\mathrm{cm})( \pm \mathrm{standard}$ deviation), range and total number of individuals $(\mathrm{N})$ of fish captured by both gear.

\begin{tabular}{|c|c|c|c|c|c|c|c|}
\hline \multirow{2}{*}{ Families } & \multirow{2}{*}{ Species } & \multirow{2}{*}{$\begin{array}{c}\text { Common } \\
\text { name }\end{array}$} & \multirow{2}{*}{ Abundance } & \multirow{2}{*}{ Biomass } & \multicolumn{3}{|c|}{ Length } \\
\hline & & & & & Mean \pm SD & Range & $\mathbf{N}$ \\
\hline Engraulidae & $\begin{array}{l}\text { Lycengraulis } \\
\text { grossidens } \\
\text { (Agassiz 1829) }\end{array}$ & $\begin{array}{l}\text { River } \\
\text { anchovy }\end{array}$ & 3.33 & 29.0 & $15.6 \pm 4.8$ & $10.5-20.1$ & $3 *$ \\
\hline \multirow[t]{2}{*}{ Clupeidae } & $\begin{array}{l}\text { Brevoortia aurea } \\
\text { (Agassiz 1829) }\end{array}$ & $\begin{array}{l}\text { Brazilian } \\
\text { menhaden }\end{array}$ & $46.8 \pm 31.8$ & $286.4 \pm 448.3$ & $15.8 \pm 10.1$ & $2.5-41.0$ & $123^{*}$ \\
\hline & $\begin{array}{l}\text { Platanichthys } \\
\text { platana } \\
\text { (Regan 1917) }\end{array}$ & $\begin{array}{l}\text { River Plate } \\
\text { sprat }\end{array}$ & $37.1 \pm 22.6$ & $31.97 \pm 31.7$ & $5.9 \pm 1.1$ & $2.8-9.3$ & 79 \\
\hline Cyprinidae & $\begin{array}{l}\text { Cyprinus carpio } \\
\text { (Linnaeus } 1758 \text { ) }\end{array}$ & $\begin{array}{l}\text { Common } \\
\text { carp }\end{array}$ & 3.33 & 7815.0 & - & 75.0 & 1 \\
\hline Ariidae & $\begin{array}{l}\text { Genidens barbus } \\
\text { (Lacepède 1803) }\end{array}$ & $\begin{array}{l}\text { Marine } \\
\text { catfish }\end{array}$ & 3.33 & 17.7 & - & 8.8 & 1 \\
\hline Mugilidae & $\begin{array}{l}\text { Mugil liza } \\
\text { Günther } 1880\end{array}$ & Mullet & $32.2 \pm 19.0$ & $155.4 \pm 173.2$ & $5.7 \pm 7.4$ & $2.7-40.3$ & $61^{*}$ \\
\hline Atherinopsidae & $\begin{array}{l}\text { Odontesthes } \\
\text { argentinensis } \\
\text { (Valenciennes } \\
\text { 1836) }\end{array}$ & Silverside & $30.2 \pm 24.0$ & $249.4 \pm 218.7$ & $13.2 \pm 5.5$ & $5.0-44.8$ & $127 *$ \\
\hline \multirow[t]{3}{*}{ Sciaenidae } & $\begin{array}{l}\text { Menticirrhus } \\
\text { americanus } \\
\text { (Linnaeus 1758) }\end{array}$ & $\begin{array}{l}\text { King } \\
\text { whiting }\end{array}$ & - & - & - & 18.0 & $1^{*}$ \\
\hline & $\begin{array}{l}\text { Micropogonias } \\
\text { furnieri } \\
\text { (Desmarest 1823) }\end{array}$ & $\begin{array}{l}\text { Whitemouth } \\
\text { croaker }\end{array}$ & $54.6 \pm 29.9$ & $79.0 \pm 63.7$ & $6.5 \pm 3.0$ & $2.1-14.9$ & $104 *$ \\
\hline & $\begin{array}{l}\text { Pogonias cromis } \\
\text { (Linné 1766) }\end{array}$ & $\begin{array}{l}\text { Black } \\
\text { drum }\end{array}$ & - & - & $42.3 \pm 17.2$ & $22.6-53.8$ & $3 *$ \\
\hline Gobiidae & $\begin{array}{l}\text { Gobiosoma parri } \\
\text { (Ginsburg 1933) }\end{array}$ & Goby & 4.44 & $1.9 \pm 1.6$ & $3.6 \pm 0.9$ & $2.9-4.2$ & 2 \\
\hline Blenniidae & $\begin{array}{l}\text { Hypleurochilus } \\
\text { fissicornis (Quoy } \\
\text { \& Gaimard 1824) }\end{array}$ & Blenny & 6.67 & 12.7 & $5.4 \pm 0.6$ & $5.0-5.8$ & 2 \\
\hline Syngnathidae & $\begin{array}{l}\text { Syngnathus folletti } \\
\text { (Herald 1942) }\end{array}$ & $\begin{array}{l}\text { Southern } \\
\text { pipefish }\end{array}$ & 6.67 & 6.0 & $14.8 \pm 0.2$ & $14.7-14.9$ & 2 \\
\hline Paralichthyidae & $\begin{array}{l}\text { Paralichthys } \\
\text { orbignyanus } \\
\text { (Valenciennes } \\
\text { 1839) }\end{array}$ & Flounder & $8.9 \pm 2.9$ & $44.3 \pm 22.5$ & $7.4 \pm 3.5$ & $3.2-112.6$ & 14 \\
\hline
\end{tabular}

* Indicate occurrence of species captured by gill net.

B. aurea $(22.6 \mathrm{~cm} \pm 11.1)$, M. liza $(31.7 \mathrm{~cm} \pm 11.7)$ and O. argentinensis $(26.5 \mathrm{~cm} \pm 5.8)$; except for the whitemouth croaker which was only represented by juveniles (14 individuals; $13.3 \mathrm{~cm} \pm 0.7$ ).

\subsection{Classification of fish species}

According to number of individuals and frequency of occurrence of species over the study period, the species O. argentinensis, P. platana (Regan, 1917), M. liza, B. aurea, M. furnieri and Paralichthys orbignyanus (Valenciennes, 1839) were classified as dominant (Figure 3 ). On the other hand, C. carpio, Genidens barbus (Lacepède, 1803), Lycengraulis grossidens (Agassiz, 1829), Gobiosoma parri (Ginsburg, 1933), Hypleurochilus fissicornis (Quoy \& Gaimard, 1824) and Syngnathus folletti (Herald, 1942) were included into the category of rare species (Figure 3). Common or occasional species were not found.

\subsection{Temporal variability of fish assemblage and} environmental factor

Autumn 2012 was the season with the highest species richness (10 species), in opposition to spring 2011 and winter 2012 when only four species were represented. Temporal analysis of the fish community abundance revealed that the highest average values of number of individuals were captured in autumn $2012\left(1010\right.$ individuals $\left.\times 1000 \mathrm{~m}^{2}\right)$ 
decreasing towards winter 2012 (253 individuals x $1000 \mathrm{~m}^{2}$ ), with the lowest values occurring during spring 2011 (60 individuals $\times 1000 \mathrm{~m}^{2}$ ). In autumn 2012 greatest abundance was registered for $M$. furnieri (300 individuals $\times 1000 \mathrm{~m}^{2}$ ) followed by $O$. argentinensis (233 individuals $\times 1000 \mathrm{~m}^{2}$ ) and $M$. liza $\left(190\right.$ individuals $\left.\times 1000 \mathrm{~m}^{2}\right)$; whereas in spring $2011, B$. aurea was the most abundant species (50 individuals $\times 1000 \mathrm{~m}^{2}$ ). In winter 2012, P. platana was the most abundant species (123 individuals x $1000 \mathrm{~m}^{2}$ ), followed by $B$. aurea (107 individuals $\times 1000 \mathrm{~m} 2)$. Besides the mentioned species, $P$. orbignyanus was also abundant in autumn 2012 (27 individuals $\left.\times 1000 \mathrm{~m}^{2}\right)$ (Figure 4). Comparing abundance between seasons, $O$. argentinensis presented the highest abundance during autumn (Kruskal-Wallis, $\mathrm{p}<0.01$ ), similar to $M$. liza

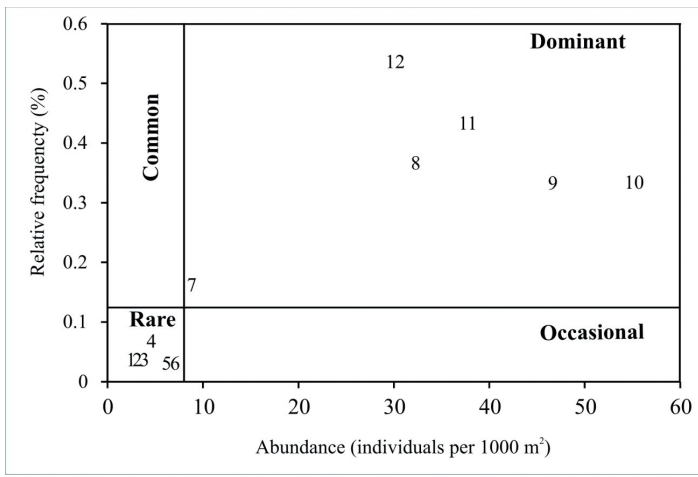

Figure 3. Olmstead-Tukey test for association (modified of González-Acosta et al., 2005) of abundance and relative frequency of fish assemblage species collected in Solís Chico subestuary. The lines dividing the quadrants correspond to the median values of the axes. 1: Cyprinus carpio; 2: Genidens barbus; 3: Lycengraulis grossidens; 4: Gobiosoma parri; 5: Hypleurochilus fissicornis; 6: Syngnathus folletti; 7: Paralichthys orbignyanus; 8: Mugil liza; 9: Brevoortia aurea; 10: Micropogonias furnieri; 11: Platanichthys platana; 12: Odontesthes argentinensis.

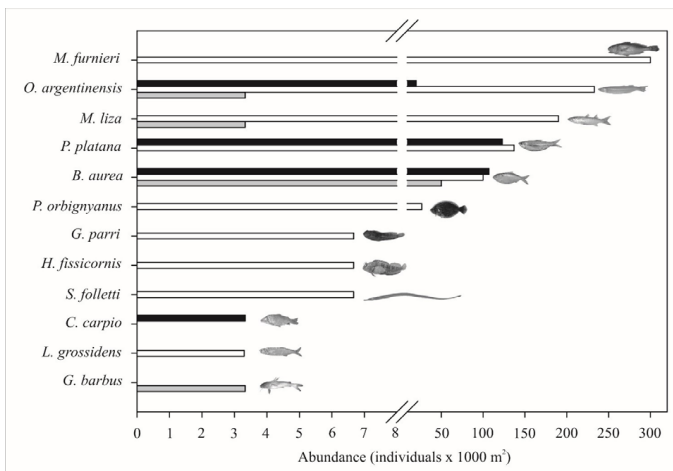

Figure 4. Seasonal distribution of species abundance (individuals $\times 1000 \mathrm{~m}^{2}$ ) during spring 2011 (grey bar), autumn (white bar) and winter 2012 (black bar) in Solís Chico subestuary.
(Kruskal-Wallis, $\mathrm{p}<0.01$ ), although the latter was absent in winter 2012. On the other hand, while P. platana occurred mostly in autumn, $B$. aurea presented its greatest number during winter 2012. Micropogonias furnieri was only registered in autumn (Figure 4).

The highest correlation were found with, temperature, probably main factor structuring temporal changes in fish community $(R=0.866)$, followed by salinity and oxygen concentration ( $R=0.500$ and $R=-0.500$, respectively).

\section{Discussion}

\subsection{Composition and structure of the fish community}

The Solís Chico subestuary presented a typical composition of species from estuarine areas located in southwest Atlantic Ocean coasts in Brazil, Uruguay and Argentina (Ramos and Vieira, 2001; Jaureguizar et al., 2003, 2004; Retta et al., 2006; González-Castro et al., 2009; Acuña-Plavan et al., 2010; Cousseau et al., 2011; Gurdek et al., 2011; Bruno et al., 2013). Captures were dominated by euryhaline species, such as $B$. aurea, $O$. argentinensis and $M$. furnieri, in coincidence with studies undertaken in the Uruguayan coast (Retta et al., 2006; Acuña-Plavan et al., 2010; Gurdek et al., 2011; Lorenzo et al., 2011). The dominance by a few species coincided with studies in temperate estuaries from the southwest Atlantic coast (Ramos and Vieira, 2001; Retta et al., 2006; González-Castro et al., 2009; Acuña-Plavan et al., 2010; Cousseau et al., 2011; Gurdek et al., 2011; Bruno et al., 2013). Other species registered in the Solís Chico were $P$. platana, a species commonly registered in estuarine waters, $M$. liza and P. orbignyanus, migrant species (Ramos and Vieira, 2001; González-Castro et al., 2009; Bruno et al., 2013) whose life cycles involved the Río de la Plata estuary and adjacent marine areas (Jaureguizar et al., 2006; Acuña et al., 2015). Lycengraulis Grossidens, despite being a resident species in freshwater, estuarine and marine environments (Mai and Vieira, 2013) generally found along the Uruguayan coast (Retta et al., 2006; Norbis et al., 2006), showed a low abundance in the Solís Chico. On the other hand, some collected species in the Solís Chico were categorized as rare. These was the case of G. parri, H. fissicornis and S. folletti, which belong to the Gobiidae, Blenniidae and Syngnathidae families respectively. In contrast to the expected, these species were not registered in adjacent sub-estuaries and they are little cited for the Uruguayan coast. These species have some common aspects, e.g., small size, bottom dwelling habits, parental care, spawning of few eggs that adhere to the substrate (Acha, 1994; Bruno et al., 2011; García et al., 2005; Mantero et al., 2006; Possamai and Fávaro, 2015) and use of vegetated areas of the Atlantic Ocean, usually in shallow coastal areas and in estuarine waters. The biology of these species remains unknown along the Uruguayan coast and there are only a few records of them (Acuña-Plavan et al., 2010; Machado, 2013; Retta et al., 2006). Regarding the species composition found in the Solís Chico, it should be considered that the sampling area was restricted to the lower area of 
the subestuary, thus probably influencing the absence of freshwater species, except for $C$. carpio, an invasive species sporadically recorded in the subestuaries and Uruguayan coast in conditions of low salinity (Fabiano et al., 1992; Rico, 2000; Acuña-Plavan et al., 2010). These results also show the potential dispersion of this invasive species in freshwater and estuarine waters of Uruguay. Finally, the little abundant G. barbus, M. americanus and P. cromis are species widely cited in the Río de la Plata estuary, where they develop their life cycles. Estuaries are essential areas for reproduction and nursery of larvae and juvenile fishes (Whitfield, 1999; Beck et al., 2001; Vidy et al., 2004). Regarding the length structure of the collected fish assemblage, a large representation by juvenile stages was observed, mainly captured by the beach seine net. This reaffirms the importance of Uruguayan subestuaries of the Río de la Plata as nursery areas (Retta et al., 2006; Acuña-Plavan et al., 2010; Acuña et al., 2015). On the other hand, passive gears, such as gill nets allowed the capture of larger species than those caught by seine netting. This can be related to movement and habitat use by fish species, where certain specimens escape more easily the trawl or tend to move to deeper estuarine areas (Potter and Pawson, 1991; Rozas and Minello, 1997; Elliott and Hemingway, 2002). The use of different gears increases the capture efficiency of fish allowing the collection of a more diverse fish assemblage, indicating that is important to consider the capture of each gear type separately (Cowley and Whitfield, 2001).

\subsection{Seasonal variation of fish assemblage and environmental factors}

The fish community of Solís Chico subestuary presented a seasonal variation with higher values of species occurrence and abundance during autumn. Spring and summer are the seasons that present the highest abundance of fish in temperate estuaries (Potter et al., 1986; Veiga et al., 2006; Selleslagh and Amara, 2008; Bruno et al., 2013), sometimes registering higher values during the autumn (Cardoso et al., 2011). This variability can be related to temperature variability and seasonal patterns related to life history cycles, such as those registered in the Pando subestuary (Acuña-Plavan et al., 2010). Also, adjacent habitats to estuaries have been suggested to play an important role in the interannual recruitment dynamics for many species (Woodland et al., 2012), attributing the seasonal peaks to the arrival of juveniles of many marine species that use shallow water ecosystems as nurseries (Veiga et al., 2006). In this sense, the fish patterns in the Solis Chico subestuary could be dependent on the Río de la Plata estuary for completing their life cycle (Acuña et al., 2015). Both, reproduction and migration processes of fish in the large estuary would influence the seasonal dynamics of juveniles in subestuaries along the Uruguayan coast. The ichthyofauna (B. aurea, C. carpio, G. barbus. M. liza, O. argentinensis, M. americanus, M. furnieri, P. cromis, P. orbignyanus) of the Solís Chico subestuary are species economic important for Uruguay and play relevant ecological role in estuarine system of the Río de la Plata that should be highlighted.

A strong positive linear relationship between temperature and the abundance of fish species in Solís Chico was found. The highest abundance of fishes during autumn 2011 was correlated with the highest values of temperature in coincidence with studies in adjacent subestuaries, such as Pando (Acuña-Plavan et al., 2010) and in the coastal zone of the Río de la Plata (Lorenzo et al., 2011). On the other hand, in spring 2011 and winter 2012 specimen abundance of fish community and temperature values was similar. Temperature has been determined as the most important abiotic factor affecting distribution of fish species in Portugal estuaries and it has been related to seasonal migrations (Pombo et al., 2005). Changes in water temperature exert a seasonal influence on the relative abundance of fish species within fish assemblages captured in the Río de la Plata estuary (Jaureguizar et al., 2004). Other hydrographic characteristics of estuarine subsystems determine the composition and structure of the fish community living there (Uphoff Junior et al., 2011), such as salinity and dissolved oxygen (Whitfield, 1999; Jung and Houde, 2003). Salinity in the subestuaries may fall or rise very fast depending on the depth and size and given the proximity of both freshwater and the marine system (Uncles and Stephens, 2010). Also, a seasonal oscillation dependent on meteorological factors can be observed (García et al., 2003). During 2011 climate conditions across the South American region were influenced by "La Niña" events, with dry seasons and low river flows (Bidegain et al., 2012). The higher salinity values registered in the Solís Chico subestuary during spring 2011 was probably affected by patterns of rainfall occurring on its basin previous to sampling (Instituto Uruguayo de Meteorología, INUMET). Moreover, low salinities registered in winter 2012 may be the result of heavy rainfall occurring in the region and higher discharge of freshwater (Instituto Uruguayo de Meteorología, INUMET). Despite two scenarios prevail (ENSO during 2011 and meteorological event in 2012), no abundance of marine fish or greater presence of freshwater fish was recorded in the subestuary, respectively.

On the other hand, dissolved oxygen was generally not a limiting factor for the occurrence of fish in the Solís Chico subestuary, showing a negative relationship with the fish abundance. During periods of low dissolved oxygen values highest values of temperature occurred, this variable may be exerting more influence on the number of fish than dissolved oxygen. In addition to these factors, the behaviour of the fish community of subestuaries is also dependent on habitat and temporary ecological aspects related to food resources and feeding availability. Concerning these points, the lower portion of the Solís Chico subestuary (adjacent to the seine netting location) presents a salt marsh area that occupies $3.4 \mathrm{~km}^{2}$ (MVOTMA, 2003). The role of these ecosystems in terms of retention of particulate organic matter and nutrients as well as suitable habitat for migratory and native flora and fauna is widely recognized (Blanco, 2003). These habitats provide shelter 
and food resources to the fishes, hence influencing on fish assemblage (França et al., 2009; Nicolas et al., 2010), also playing a crucial role in maintaining biodiversity in aquatic systems, particularly for fish (Pasquaud et al., 2008). In Solís Chico subestuary, Stebniki (2014) found mainly zooplankton, phytoplankton and zoobenthos in the diet of fish, recording seasonal variability in food intake.

In addition to environmental variables, human activities are also affecting Uruguayan coastal fish communities, including those of the subestuaries of the Río de la Plata (PNUMA and IMC, 2009; Gutiérrez et al., 2015). The main anthropogenic activities in the Solís Chico basin are related to agriculture, forestry and summer tourism (MVOTMA, 2003; Goyenola et al., 2009). Also, irreversible modifications were made on the west margin of the stream near its mouth, where a retaining wall was constructed and a salt marsh was destroyed (Retta et al., 2006; Solari et al., 2014). Thus it is important to ensure that key habitats will be managed and conserved appropriately, since these are the habitats for early stages of fish of economic and biological importance.

\section{Conclusion}

The fish assemblage of Solís Chico subestuary is typical of the Uruguayan coast estuarine systems and was characterized by the presence of euryhaline fishes, target species for Uruguay fisheries and was home to rare species. Seasonality influenced on the changes in fish abundance, which was can be explained by sharing fish life cycles between the Río de la Plata and the Uruguayan coast subestuaries.

\section{Acknowledgements}

We thank the fisherman Alfredo Hargain for his participation in the fishing activities and to the Professor Rafael Arocena and the Limnology laboratory (Facultad de Ciencias, Universidad de la República) for lending us the boat. Special thanks to the IctioEstuarios Project team: Ruben Canavesse, Samanta Stebniki, Vernadet Bianchinotti, Andrés de la Rosa, Veronica Severi, Martín Sosa and Diego Corrales who helped us in the field and laboratory activities. This work was funded by a full time program of Universidad de la República (2012-2013), PEDECIBA (2012) (Programa de Desarrollo de las Ciencias Básicas and an Initial Fellowship (ANII, Agencia Nacional de Investigación e Inovación, 2011-2012).

\section{References}

ABLE, K.W., 2005. A re-examination of fish estuarine dependence: evidence for connectivity between estuarine and ocean habitats. Estuarine, Coastal and Shelf Science, vol. 64, no. 1, pp. 5-17. $\mathrm{http} / / / \mathrm{dx}$. doi.org/10.1016/j.ecss.2005.02.002.

ACHA, E., 1994. Development and ocurrence of larvae of the goby, Gobiosoma parri (Ginsburg) (Gobiidae), in the estuary of the Río de la Plata, Argentina. Scientia Marina, vol. 58, no. 4, pp. 337-343.
ACUÑA, A., VEROCAI, J., GURDEK, R., MUÑOZ, N., CANAVESE, R., MACHADO, I., DE LA ROSA, A., SEVERI, V., STEBENIKI, S., GUTIERREZ, J. and CORREA, P., 2015. Estuarios del Uruguay. Biodiversidad y estructura de la asociación de peces. In: P. MUNIZ, D. CONDE, N. VENTURINI and E. BRUGNOLI, compiladores. Ciencias marino-costeras en el umbral del siglo XXI: Desafios en Latinoamérica y el Caribe. Ciudad de México: AGT- Editor S.A.

ACUÑA-PLAVAN, A., PASSADORE, C. and GIMÉNEZ, L., 2010. Fish assemblage in the temperate estuary on the Uruguayan coast: seasonal variation and environmental influence. Brazilian Journal of Oceanography, vol. 58, pp. 299-314.

BECK, M.W., HECK, K.L., ABLE, K.W. Jr., CHILDERS, D.L., EGGLESTON, D.B., GILLANDERS, B.M., HALPERN, B., HAYS, C.G., HOSHINO, K., MINELLO, T.J., ORTH, R.J., SHERIDAN, P.F. and WEINSTEIN, M.P., 2001. The identification, conservation, and management of estuarine and marine nurseries for fish and invertebrates. Bioscience, vol. 51, no. 8, pp. 633-641. http://dx.doi. org/10.1641/0006-3568(2001)051[0633:TICAMO]2.0.CO;2.

BEMVENUTI, M.A., 2002. Diferenciação morfológica das espécies de peixes-rei Odontesthes Evermann and Kendall (Osteichthyes, Atherinopsidae) no extremo sul do Brasil: morfometriam ultivariada. Revista Brasileira de Zoología, Curitiba, vol. 19, no. 1, pp. 239-249.

BIDEGAIN, M., SKANSI, M., PENALBA, O. and QUINTANA, J., 2012. Southern South America. In: J. BLUNDEN and D.S. ARNDT, eds. State of the climate in 2011. Special Supplement to the Bulletin of the American Meteorological Society, vol. 93, no. 7 , p. $177 \mathrm{~S}-178 \mathrm{~S}$

BLANCO, A.C., 2003. Evaluación estratégica ambiental y desarrollo metodológico destinada a la gestión sostenible de la fuente de agua potable: cuenca del $A^{\circ}$ Solis Chico como fuente alternativa para el abastecimiento de agua potable. Montevideo: Universidad de la República, 318 p. Disertación de Maestría en Ciencias Ambientales.

BRUNO, D., ADDINO, M. and DÍAZ DE ASTARLOA, J., 2011. Southernmost occurrence of Syngnathus folletti on a temperate coastal lagoon of Argentina. Marine Biodiversity Records: Marine Biological Association of the United Kingdom, vol. 4, no. 62 , pp. 1-3.

BRUNO, D.O., BARBINI, S.A., DÍAZ DE ASTARLOA, J.M. and MARTOS, P., 2013. Fish abundance and distribution patterns related to environmental factors in a choked temperate coastal lagoon (Argentina). Brazilian Journal of Oceanography, vol. 61, no. 1, pp. 43-53. http://dx.doi.org/10.1590/S1679-87592013000100005.

CARDOSO, I., FRANÇA, S., PESSANHA, M., HENRIQUES, S., FONSECA, L. and CABRAL, H.N., 2011. Fish assemblages of small estuaries of the Portuguese coast: a functional Approach. Marine Pollution Bulletin, vol. 62, pp. 992-1001. PMid:21396662. http://dx.doi.org/10.1016/j.marpolbul.2011.02.037.

CAYSSIALS, R., HERNÁNDEZ, J., CANTÓN, V., FERNÁNDEZ, V., LABORDE, J.L. and COLLAZO, D., 2000. Caracterización del medio físico. In: J.L. LABORDE, A. PERDOMO and M. GÓMEZ-ERACHE, eds. Diagnóstico ambiental y sociodemográfico de la zona costera uruguaya del Río de la Plata. Montevideo: ECOPLATA, pp. 14-73.

CLARKE, K. R., 1993. Non-parametric multivariate analyses of changes in community structure. Australian Journal of Ecology, vol. 18, pp. 117-143. 
CLARKE, K.R. and WARWICK, R.M., 1994. Change in marine communities: an approach to statistical analysis and interpretation. Plymouth: Plymouth Marine Laboratory. 859 p.

CLARKE, K.R. and WARWICK, R.M., 2001. Change in marine communities: an approach to statistical analysis and interpretation. 2nd ed. Plymouth: PRIMER-E. 172 p.

COUSSEAU, M.B., MARCHESI, M.C., FIGUEROA, D.E., DÍAZ DE ASTARLOA, J.M. and GONZÁLEZ-CASTRO, M., 2011. Relación íctica entre la laguna costera Mar Chiquita y el mar adyacente. Historia Natural (Tercera Serie), vol. 1, pp. 85-100.

COWLEY, P.D. and WHITFIELD, A.K., 2001. Ichthyofaunal characteristics of a typical temporarily open/closed estuary on the South East coast of South Africa. Ichthyological Bulletin, vol. 71, pp. 1-17.

DAWSON, C.E., 1982. Family Syngnathidae. In: J.E. BOLKE, ed. Fishes of the western North Atlantic: part eight: order gasteroisteiformes, suborder syngnathoidei. New Haven: Sears Foundation for Marine Science. 198 p.

DYER, H.B.S., 2006. Systematic revision of the South American silversides (Teleostei, Atheriniformes). Biocell, vol. 30, no. 1, pp. 69-88. PMid:16845831.

ELLIOTT, M. and HEMINGWAY, K.L., 2002. Fishes in Estuaries. Oxford: Blackwell Science. 636 p.

FABIANO, G., AMESTOY, F., GARCÍA, C. and ARES, L., 1992. Estudio de las variaciones en la abundancia, la estructura y la distribución espacio-temporal de los efectivos de carpa común, Cyprinus carpio, en el Río de la Plata medio e interior y en el Río Uruguay inferior. Publicaciones de la Comisión Administradora del Río Uruguay: Serie Técnico-Científica, vol. 1, pp. 13-24.

FIGUEIREDO, J.L. and MENEZES, N.A., 1978. Manual de peixes marinhos do sudeste do Brasil. II. Teleostei (1). Sao Paulo: Museu de Zoología da Universidade de São Paulo. 110 p.

FIGUEIREDO, J.L. and MENEZES, N.A., 1980. Manual de peixes marinhos do sudeste do Brasil. III. Teleostei (2). Sao Paulo: Museu de Zoología da Universidade de São Paulo. 98 p.

FIGUEIREDO, J.L. and MENEZES, N.A., 2000. Manual de peixes marinhos do sudeste do Brasil. VI. Teleostei (5). Sao Paulo: Museu de Zoología da Universidade de São Paulo. 116 p.

FRANÇA, S., COSTA, M.J. and CABRAL, H.N., 2009. Assessing habitat specific fish assemblages in estuaries along the Portuguese coast. Estuarine, Coastal and Shelf Science, vol. 83, no. 1, pp. 1-12. http://dx.doi.org/10.1016/j.ecss.2009.03.013.

GARCÍA, A.M., GERALDI, R.M. and VIEIRA, J.P., 2005. Diet composition and feeding strategy of the southern pipefish Syngnathus folletti in a Widgeon grass bed of the Patos Lagoon Estuary, RS, Brazil. Neotropical Ichthyology, vol. 3, no. 3, pp. 427-432. http://dx.doi.org/10.1590/S1679-62252005000300011.

GARCÍA, A.M., VIEIRA, J.P. and WINEMILLER, K.O., 2003. Effects of 1997-1998 El Niño on the dynamics of the shallowwater fish assemblage of the Patos Lagoon Estuary (Brazil). Estuarine, Coastal and Shelf Science, vol. 57, no. 3, pp. 489-500. http://dx.doi.org/10.1016/S0272-7714(02)00382-7.

GEO-URUGUAY. 2008. Informe del estado del ambiente. Montevideo: Dirección Nacional de Medio Ambiente. vol. 3, pp. 120-176.

GIMÉNEZ, L., 2003. Potencial effects of physiological plastic responses to salinity on population networks of the estuarine crab Chasmaganthus granulata. Helgoland Marine Research, vol. 56 , pp. 265-273

GONZÁLEZ-ACOSTA, A.F., DE LA CRUZ-AGÜERO, G., CRUZ-AGÜERO, J. and RUIZ-CAMPOS, G., 2005. Seasonal pattern of the fish assemblage of El Conchalito mangrove swamp, La Paz Bay, Baja California Sur, Mexico. Hidrobiológica, vol. 15 , pp. 205-214.

GONZÁLEZ-CASTRO, M., DÍAZ DE ASTARLOA, J.M., COUSSEAU, M.B., GUEROA, E., DELPIANI, S.M., BRUNO, D.O., GUZZONI, J.M., BLASINA, G.E. and DELLI ANTONI, M.Y., 2009. Fish composition in a south-western Atlantic temperate coastal lagoon: spatial-temporal variation and relationships with environmental variables. Journal Marine Biological Association, vol. 89, pp. 593-604.

GOYENOLA, G., ACEVEDO, S., MACHADO, I. and MAZZEO, N., 2009. Estado del Ambiente. In: PROGRAMA DE LAS NACIONES UNIDAS PARA EL MEDIO AMBIENTE. GEO Canelones: Informe Ambiental. Montevideo: PNUMA/IMC, pp. $59-137$.

GURDEK, R. and ACUÑA-PLAVAN, A.P., 2014. Weight-length relationships of 12 fish species from the Pando tidal creek estuary (subsystem of the Río de la Plata, Uruguay). Journal of Applied Ichthyology, vol. 30, no. 2, pp. 426-427. http://dx.doi. org/10.1111/jai.12241

GURDEK, R., MUÑOZ, N., PUPPI, V., BIANCHINOTTI, V. and ACUÑA, A., 2011. Variación nictimeral de la ictiofauna de la región estuarial del Arroyo Solís Grande, Uruguay. Boletin de la Sociedad Zoológica del Uruguay, vol. 20, pp. 11-21.

GUTIÉRREZ, J.M., VILLAR, S. and ACUÑA PLAVAN, A., 2015. Micronucleus test in fishes as indicators of environmental quality in subestuaries of the Río de la Plata (Uruguay). Marine Pollution Bulletin, vol. 91, no. 2, pp. 518-523. PMid:25455785. http://dx.doi.org/10.1016/j.marpolbul.2014.10.027.

JAUREGUIZAR, A.J., MENNI, R., BREMEC, C., MIANZAN, H. and LASTA, C., 2003. Fish assemblage and environmental patterns in the Río de la Plata estuary. Estuarine, Coastal and Shelf Science, vol. 56, no. 5-6, pp. 921-933. http://dx.doi.org/10.1016/ S0272-7714(02)00288-3.

JAUREGUIZAR, A.J., MENNI, R., GUERRERO, R. and LASTA, C., 2004. Environmental factors structuring fish communities of the Río de la Plata estuary. Fisheries Research, vol. 66, no. 2-3, pp. 195-211. http://dx.doi.org/10.1016/S0165-7836(03)00200-5.

JAUREGUIZAR, A.J., MENNI, R., LASTA, C. and GUERRERO, R., 2006. Fish assemblages of the northern Argentine coastal system: spatial patterns and their temporal variations. Fisheries Oceanography, vol. 15, no. 4, pp. 326-344. http://dx.doi. org/10.1111/j.1365-2419.2006.00405.x.

JUNG, S. and HOUDE, E.D., 2003. Spatial and temporal variabilities of pelagic fish community structure and distribution in Chesapeake Bay, USA. Estuarine, Coastal and Shelf Science, vol. 58, no. 2, pp. 335-351. http://dx.doi.org/10.1016/S0272-7714(03)00085-4.

LELLIS, K.A.D., MCGLYNN, K.E. and BIGFORD, T.E., 2008. Estuarine fish and shellfish species in U.S. Commercial and recreational fisheries: economic value as an incentive to protect and restore estuarine habitat. Washington, D.C.: U.S. Departament of Commerce. NOAA Tech. Memo, NMFSF/SPO-90.

LORENZO, I., DÍAZ DE ASTARLOA, J.M., NORBIS, W. and COUSSEAU, M.B., 2011. Long term fish assemblages as units of management in a temperate estuary (Río de la Plata SW 
Atlantic Ocean). Brazilian Journal of Oceanography, vol. 59, no. 1 , pp. $43-59$

MACHADO, I., 2013. Condición nutricional en larvas de peces y su relación con la disponibilidad y calidad del alimento en un estuario de la costa uruguaya. Montevideo: Universidad de la República. 73 p. Disertación de Maestría en Biología.

MAI, A.C.G. and VIEIRA, J.P., 2013. Review and consideration on habitat use, distribution and life history of Lycengraulis grossidens (Agassiz, 1829) (Actinopterygii, Clupeiformes, Engraulidae). Biota Neotropical, Brazil, vol. 13, no. 3, pp. 121-130. http:// dx.doi.org/10.1590/S1676-06032013000300015.

MANTERO, G., RETTA, S. and RODRÍGUEZ, M., 2006. Ictioplancton costero de la zona de transición estuarina del Río de la Plata (Uruguay). In: R. MENAFRA, L. RODRÍGUEZGALLEGO, F. SCARABINO and D. CONDE, eds. Bases para la conservación y manejo de la costa uruguaya. Montevideo: Vida Silvestre Uruguay, pp. 437-445.

MARCENIUK, A.P., 2005. Chave para identificacao das espécies de bagres marinos (Siluriformes, Ariidae) da costa brasilera. Boletim do Instituto de Pesca, Sao Paulo, vol. 31, no. 2, pp. 89-101.

MENEZES, N.A. and FIGUEIREDO, J.L., 1980. Manual de peixes marinhos do sudeste do Brasil. IV. Teleostei (3). Sao Paulo: Museu de Zoología da Universidade de São Paulo. 96 p.

MENEZES, N.A. and FIGUEIREDO, J.L., 1985. Manual de peixes marinhos do sudeste do Brasil. V. Teleostei (4). Sao Paulo: Museu de Zoología da Universidade de São Paulo. 96 p.

MENNI, R.C., RINGUELET, R.A. and ARAMBURU, R.H., 1984. Peces marinos de la Argentina y Uruguay. Buenos Aires: Editorial Hemisferio Sur. 359 p.

MINISTERIO DE VIVIENDA, ORDENAMIENTO TERRITORIAL Y MEDIO AMBIENTE-MVOTMA, 2003. Cuencas Hidrográficas tributarias al Río de la Plata y su Frente Marítimo. Proyecto "Protección Ambiental del Río de la Plata y su Frente Marítimo: Prevención y Control de la Contaminación y Restauración de Hábitats". Proyecto Freplata, PNUD/GEF/RLA/99/G31. Documento de trabajo $\mathrm{N}^{\circ} 3$.

NICOLAS, D., LOBRY JUNIOR, L.E., LE PAPE, O. and BOËT, P., 2010. Functional diversity in European estuaries: Relating the composition of fish assemblages to the abiotic environment. Estuarine, Coastal and Shelf Science, vol. 88, no. 3, pp. 329-338. http://dx.doi.org/10.1016/j.ecss.2010.04.010.

NORBIS, W., PAESCH, L. and GALLI, O., 2006. Los recursos pesqueros de la costa de Uruguay: ambiente, biología y gestión. In: R. MENAFRA, L. RODRÍGUEZGALLEGO, F. SCARABINO and D. CONDE, eds. Bases para la conservación y manejo de la costa uruguaya. Montevideo: Vida Silvestre Uruguay, pp. 197-209.

PASQUAUD, S., ELIE, P., JEANTET, C., BILLY, I., MARTINEZ, P. and GIRARDIN, M., 2008. A preliminary investigation of the fish food web in the Gironde estuary, France, using dietary and stable isotope analyses. Estuarine, Coastal and Shelf Science, vol. 78, no. 2, pp. 267-279. http://dx.doi.org/10.1016/j.ecss.2007.12.014.

POMBO, L., ELLIOTT, M. and REBELO, J.E., 2005. Environmental influences on fish assemblage distribution of an estuarine coastal lagoon, Ria de Aveiro (Portugal). Scientia Marina, vol. 69, no. 1, pp. 143-159. http://dx.doi.org/10.3989/scimar.2005.69n1143.

POSSAMAI, B. and FÁVARO, L.F., 2015. Using mariculture as a breeding site: reproduction of Hypleurochilus fissicornis (Actinopterygii: Blenniidae). Scientia Marina, vol. 79, no. 3, pp. 335-343. http://dx.doi.org/10.3989/scimar.04176.19B.
POTTER, E.C.E. and PAWSON, M.G., 1991. Gill netting. Lowestoft: Laboratory Leaflet. 34 p. MAFF Directory Fishery Research, no. 69.

POTTER, I.C., CLARIDGE, P.N. and WARWICK, R.M., 1986. Consistency of seasonal changes in an estuarine fish assemblage. Marine Ecology Progress Series, vol. 32, pp. 217-228. http:// dx.doi.org/10.3354/meps032217.

PROGRAMA DE LAS NACIONES UNIDAS PARA EL MEDIO AMBIENTE - PNUMA, INTENDENCIA MUNICIPAL DE CANELONES - IMC. 2009. GEO canelones: informe ambiental. Montevideo: PNUMA/IMC. vol. 1, 181 p.

RAMOS, L.A. and VIEIRA, J.P., 2001. Composição específica e abundância de peixes de zonas rasas dos cinco estuários do rio Grande do Sul, Brasil. Boletim Instituto de Pesca, Brasil, vol. 27, pp. 109-121.

RANGEL, C.A. and GUIMARÃES, R.Z.P., 2010. Taxonomia e distribuição da família Blenniidae (Teleostei: Blennioidei) na costa leste do Brasil. Revista Brasileira de Zoociências, vol. 12, no. 1 , pp. 17-41

RETTA, S., MARTÍNEZ, G. and ERREA, A., 2006. Áreas de cría de especies de peces en la costa uruguaya. In: R. MENAFRA, L. RODRÍGUEZ-GALLEGO, F. SCARABINO and D. CONDE, eds. Bases para la conservación y manejo de la costa uruguaya. Montevideo: Vida Silvestre Uruguay, pp. 211-217.

RICO, M.R., 2000. La salinidad y la distribución espacial de la ictiofauna en el estuario del Río de la Plata. Argentina: Universidad Nacional de Mar del Plata. 65 p. Disertación de Grado en Ciencias Biológicas.

RINGUELET, R.A., ARAMBURU, R.H. and DE ARAMBURU, A.A., 1967. Los peces argentinos de agua dulce. La Plata: Comisión de Investigación Científica. 602 p.

ROZAS, L.P. and MINELLO, T.J., 1997. Estimating densities of small fishes and decapod crustaceans in shallow estuarine habitats: a review of sampling design with focus on gear selection. Estuaries, vol. 20, no. 1, pp. 199-213. http://dx.doi.org/10.2307/1352731.

SELLESLAGH, J. and AMARA, R., 2008. Environmental factors structuring fish composition and assemblages in a small macrotidal estuary (eastern English Channel). Estuarine, Coastal and Shelf Science, vol. 79, no. 3, pp. 507-517. http://dx.doi.org/10.1016/j. ecss.2008.05.006.

SHAPIRO, S.S. and WILK, M.B., 1965. An analysis of variance test for normality (Complete samples). Biometrika, vol. 52, no. 3-4, pp. 591-611. http://dx.doi.org/10.1093/biomet/52.3-4.591.

SOKAL, R.R. and ROHLF, J.F., 1969. Biometria. Gordonsville: W.H. Freeman and Company. 832 p.

SOLARI, S., CHRETIES, C.H., LÓPEZ, G. and TEIXEIRA, L., 2014. Analysis of the recent evolution of the sand spit at the Solís Chico River mouth. Journal of Coastal Research, vol. 70, pp. 616-620.

STEBNIKI, S., 2014. Hábitos tróficos de los peces de los Estuarios Pando, Solís Chico y Solís Grande (Dpto. Canelones, Uruguay). Montevideo: Universidad de la República. 40 p. Disertación de Grado en Ciencias Biológicas.

TOMCZAK, M., 1998 [viewed 06 November 2015]. Shelf and coastal oceanography [online]. Adelaide. Available from http:// www.es.flinders.edu.au/ mattom/ShelfCoast/index.html

UNCLES, R.J. and STEPHENS, J.A., 2010. Turbidity and sediment transport in a muddy sub-estuary. Estuarine, Coastal and Shelf 
Science, vol. 87, no. 2, pp. 213-224. http://dx.doi.org/10.1016/j. ecss.2009.03.041.

UPHOFF JUNIOR, J.H., MCGINTY, M., LUKACOVIC, R., MOWRER, J. and PYLE, B., 2011. Fish distribution in chesapeake bay subestuaries: impervious surface, summer dissolved oxygen, and fish distribution in chesapeake bay subestuaries: linking watershed development, habitat conditions, and fisheries management. North American Journal of Fisheries Management, vol. 31, no. 3, pp. 554-566. http://dx.doi.org/10.1080/02755947.2011.598384.

VEIGA, P., VIEIRA, L., BEXIGA, C., SÁ, R. and ERZINI, K., 2006. Structure and temporal variations of fish assemblages of the Castro Marim salt marsh, southern Portugal. Estuarine, Coastal and Shelf Science, vol. 70, no. 1-2, pp. 27-38. http:// dx.doi.org/10.1016/j.ecss.2006.05.037.
VIDY, G., DARBOE, F.S. and MBYE, E.M., 2004. Juvenile fish assemblages in the creeks of the Gambia Estuary. Aquatic Living Resources, vol. 17, no. 1, pp. 56-64. http://dx.doi.org/10.1051/ alr:2004008.

WHITFIELD, A.K., 1999. Ichthyofaunal assemblages in estuaries: a South African study. Reviews in Fish Biology and Fisheries, vol. 9, no. 2, pp. 151-186. http://dx.doi.org/10.1023/A:1008994405375.

WOODLAND, R.J., SECOR, D.H., FABRIZIO, M.C. and WILBERG, M.J., 2012. Comparing the nursery role of inner continental shelf and estuarine habitats for temperate marine fishes. Estuarine, Coastal and Shelf Science, vol. 99, pp. 61-73. http://dx.doi.org/10.1016/j.ecss.2011.12.019. 